\title{
Long-term changes of intertidal and subtidal sediment compositions in a tidal basin in the northern Wadden Sea (SE North Sea)
}

\author{
Tobias Dolch $\cdot$ H. Christian Hass
}

Received: 19 June 2007 / Revised: 20 September 2007 / Accepted: 20 September 2007 / Published online: 21 November 2007

(C) Springer-Verlag and AWI 2007

\begin{abstract}
Wadden Sea tidal flats are highly dynamic regarding the spatial distribution and the grain size composition of their sediments. From 2003 to 2006 surface sediments have been surveyed in an intertidal and a subtidal area within the tidal inlet Königshafen (south-eastern North Sea, northern Wadden Sea, island of Sylt) with the goal to gain information on short-term development trends in the grain size composition. The average grain size (Mean) becomes finer in the sheltered part of the intertidal survey area whereas a coarsening tendency can be observed in the more exposed part of the intertidal and especially in the subtidal survey area. The trend of the most frequent grain size (first Mode) shows the same spatial distribution pattern but is far less distinct. Thus, the changing Mean must be related to an increase in the deposition of fines in the sheltered part of the intertidal Königshafen as well as a general removal of fine-grained material in the exposed intertidal and subtidal Königshafen. In order to see long-term trends the surveys of 2003-2006 were compared to earlier studies conducted in 1932/1933, 1981 and 1989. A significant depletion of mud can be observed in the entire survey area. It is concluded that primarily changed hydrodynamics that may accompany ongoing climate change are responsible for this. However, the loss of fine-grained sediments is additionally amplified by a reduced vegetation cover and coastal protection measures.
\end{abstract}

Communicated by J. van Beusekom.

T. Dolch $(\bowtie) \cdot$ H. C. Hass

Alfred Wegener Institute for Polar and Marine Research, Wadden Sea Station Sylt, Hafenstrasse 43, 25992 List, Germany e-mail: Tobias.Dolch@awi.de

H. C. Hass

e-mail: Christian.Hass@awi.de
Keywords Grain size composition · Intertidal · Subtidal · Depletion of mud $\cdot$ Hydrodynamics

\section{Introduction}

The shore of the south-eastern North Sea is characterised by unconsolidated sediments and its morphology is driven by hydrodynamics (Flemming and Bartholomä 2003). This results in a highly dynamic system which changes continuously. Dynamic equilibriums are often found but other changes are continuous and lead to new conditions.

The grain size composition of sediment reflects information on the prevailing hydrodynamics. In particular subtle changes in speed and force of the tidal currents leave traces in the granulometry of associated sediments. In addition, biological factors like seagrass coverage (Ward et al. 1984; Fonseca and Fisher 1986; Heiss et al. 2000), mussel beds (Widdows et al. 2002) or the presence of the lugworm Arenicola marina (Wohlenberg 1937; Volkenborn and Reise 2006) can have a significant impact on the sediment composition. Changes in the grain size composition of Wadden Sea sediments can also be man-made. The reduction of a tidal catchment area leads to increased energy-levels in a tidal basin which results in a depletion of mud (Flemming and Nyandwi 1994; Mai and Bartholomä 2000). Another man-made cause is mechanical cockle-dredging which increases resuspension and erosion of fine-grained sediments, also resulting in a coarsening (Piersma et al. 2001). As no heavy mussel fishery occurs in the List tidal basin, there must be other reasons for the change in the sediment composition.

Our hypothesis is that ongoing climate change and sea level rise leave a signal in surface sediments and that intertidal and subtidal sediments are differently affected. The 
aim of this study is to gain information on short-term changes in the grain size composition as well as on longterm changes in the share and spatial distribution of different sediment types in order to reveal possible relation to environmental change. For the short-term view, intertidal and subtidal surface sediments were monitored over 3 years in a time-series investigation in the inner, intertidal and outer, subtidal Königshafen, a semi-enclosed bay in the north of the island of Sylt (south-eastern North Sea, northern Wadden Sea, Germany). For each sediment sample the average grain size (Mean) and the most frequent grain size (first Mode) were analysed as parameters describing changes in the sediment composition. In order to get a longterm perspective of the depositional processes and to see real trends in their development we compared our present survey with former studies that have been done by Wohlenberg (1937), Felix (1981) and Austen (1990).

\section{Study area}

This study was conducted in the Königshafen $\left(55^{\circ} 02^{\prime} \mathrm{N}\right.$, $8^{\circ} 25^{\prime} \mathrm{E}$ ), a sheltered tidal bay in the northern part of the island of Sylt (south-eastern North Sea, Germany; Fig. 1a). This bay is part of the List tidal basin, a $401 \mathrm{~km}^{2}$ large bight in the northern Wadden Sea. The Königshafen is almost completely enclosed except for an opening in the east (Fig. 1b). Water is mainly exchanged through a central tidal creek that enters the Königshafen north of the exposed tidal flats "Uthörner Aussenwatt". The Königshafen is divided into the shallow, intertidal, inner Königshafen in the west and the subtidal, outer Königshafen in the east. The tides are semi-diurnal, with a mean tidal range of $1.8 \mathrm{~m}$ (Backhaus et al. 1998). Generally at low tide, the entire inner Königshafen falls dry except of the central tidal creek, while the outer Königshafen is always covered with water at a ranging water depth between 2 and $8 \mathrm{~m}$. Water levels, as well as current velocities, are affected by wind direction and wind force. Westerly winds lead to higher water levels. This is further amplified with increasing wind speed. On the other hand are lower water levels caused by easterly winds (Backhaus et al. 1998; Behrens et al. 1997). Maximum current velocities of $0.6 \mathrm{~m} \mathrm{~s}^{-1}$ can be measured in the main channels of the List tidal basin but on the tidal flats the velocities are often below $0.1 \mathrm{~m} \mathrm{~s}^{-1}$ due to the shallow terrain (Backhaus et al. 1998). As the outer Königshafen forms the connection to the List tidal basin and borders one of its main tidal channels (Lister Ley, see Fig. 1a), it is much more exposed to stronger currents than the sheltered inner Königshafen. The Königshafen seems to be ebb-dominated as this can be derived from the shapes of the megaripples.

Tidal flats in the List tidal basin comprise $33 \%$ of the area. Sand is the prevailing sediment type and covers $72 \%$
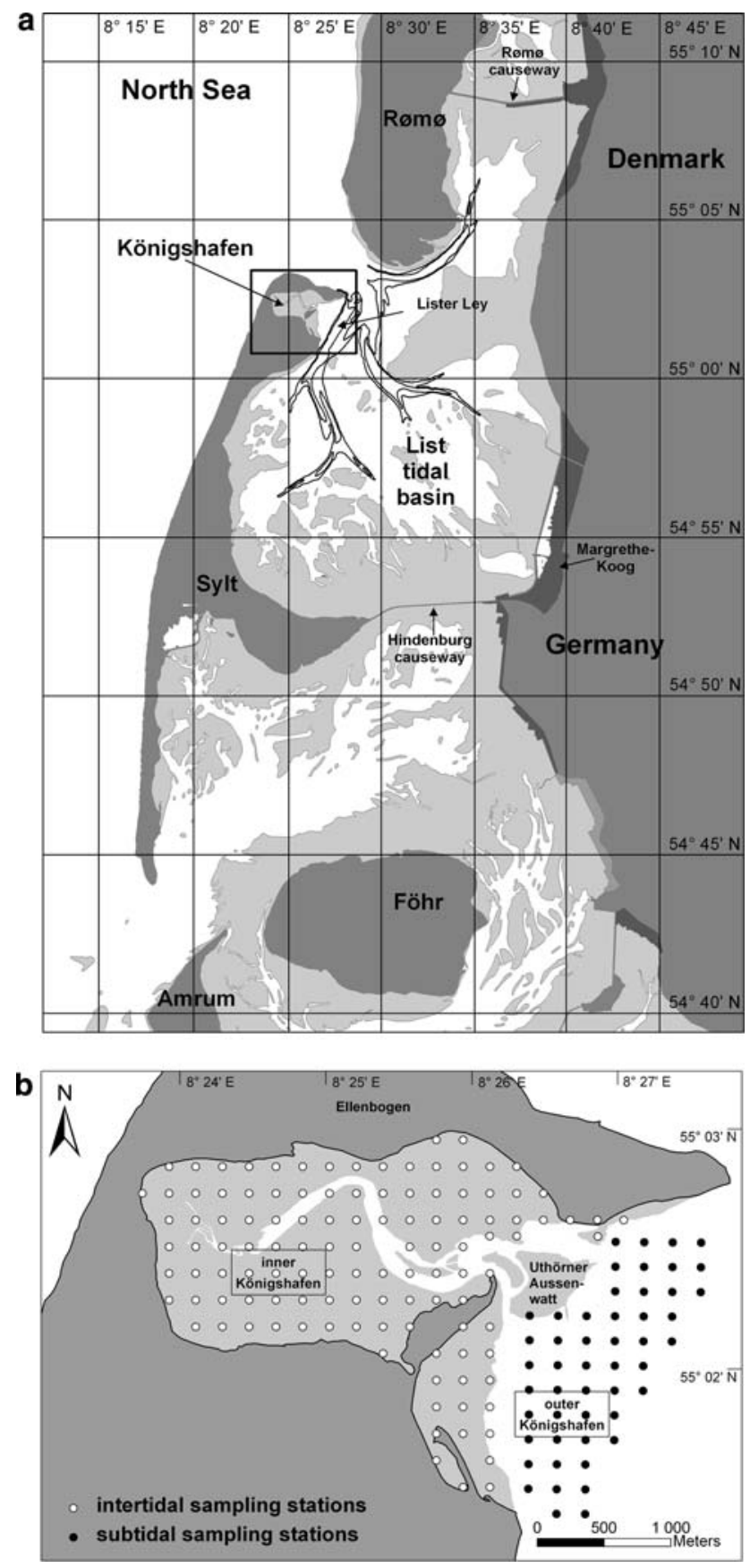

Fig. 1 a The List tidal basin in the northern Wadden Sea with the Königshafen at the northern top of the island of Sylt. $\mathbf{b}$ The study area Königshafen with the tidal flats (light grey) and the intertidal und subtidal sampling stations

of the total intertidal area (Bayerl et al. 1998). The sediments in the Königshafen also primarily consist of medium sand $(80 \%)$. But mud and fine sands can be found in sheltered locations.

Two study sites were selected in the Königshafen: the entire inner Königshafen $\left(4.8 \mathrm{~km}^{2}\right)$ and a $2.2 \mathrm{~km}^{2}$ large sampling area in the outer Königshafen. 


\section{Materials and methods}

A grid of equally distributed sampling points with a distance of $200 \mathrm{~m}$ was designed for the survey areas with 117 sampling stations in the intertidal and 50 in the subtidal zone (Fig. 1b). The sampling in the intertidal survey area was carried out during low tide from November 2004 until December 2006 with a sampling interval of 6-8 weeks depending on low water level. All together, 15 samplings campaigns were carried out and 1,626 samples taken. The sampling points were located using a differential GPS receiver with submeter accuracy. A small sediment sample (6-8 g) was collected from the surface of each sampling location. The sampling interval for the subtidal zone was every 4 weeks from August 2003 until July 2005. All together, 22 samplings campaigns were carried out here and 1,058 samples taken. The sampling was conducted with a small box corer from a research vessel. For grain size analysis a small sub-sample $(6-8 \mathrm{~g})$ was taken from the sediment surface of the box corer.

All sediment samples were treated with acetic acid and hydrogen peroxide to destroy non-siliclastic materials. The grain size composition was analysed in the lab with a CILAS 1180 Laser particle analyzer. This instrument provides a measuring range of 14.6 to $-1.4 \mathrm{Phi}(0.04$ $2,500 \mu \mathrm{m}$ ) with a class resolution of $0.1 \mathrm{Phi}$. The resulting data sets were edited and further analysed using "Gradistat", a grain size distribution and statistics package for the analysis of unconsolidated sediments (Blott and Pye 2001). The grain size statistics were georeferenced in the Geographic Information System (GIS) ArcGIS 9.1.

Two classification systems were determined regarding the type of the sediments and the trend of their development. In order to respond to the specific sediments in the Königshafen and to show even subtle developments and changes in their composition, an own classification was determined for the sampling period 2003-2006. The classification of the sediment types is given in Table 1. It was designed following the classification DIN 4022 (mud $>4 \mathrm{Phi}$, sand 4 to $-1 \mathrm{Phi}$ and gravel $<-1 \mathrm{Phi}$; these classes are further subdivided, for more information see Austen 1990). But in order to increase resolution, mud (according to DIN $4022>4$ Phi) was divided into mud and coarse mud.

Table 1 The classification of the sediment types in the Königshafen

\begin{tabular}{ll}
\hline Sediment & First mode (Phi) \\
\hline Mud (S 1) & $>6$ \\
Coarse mud (S 2) & $6-4$ \\
Fine sand (S 3) & $4-2.5$ \\
Medium sand (S 4) & $2.5-1$ \\
Coarse sand (S 5) & $<1$
\end{tabular}

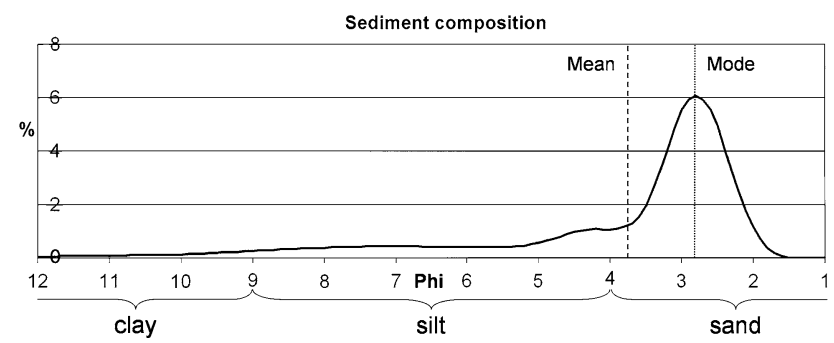

Fig. 2 The grain size composition of an exemplary sediment sample

Unlike to the DIN 4022, coarse sand had to be determined $<1$ Phi according to the output of the already classified data by the CILAS 1180 Laser particle analyzer.

For the trend of the sediments the average grain size (Mean) and the most frequent grain size (first Mode) were regarded. The differences between Mean and first Mode are illustrated in Fig. 2. Even though we focus on these two values it should be kept in mind that a sediment sample is composed of a broad range of grain size classes as shown exemplarily in Fig. 2. The trend shows if there is a steady development in the grain size composition at a certain location. For each sampling location the development of the Mean value and first Mode value, expressed in $\mu \mathrm{m}$, were plotted over the entire sampling period. Then, each sampling location was classified according to the incline or decline of the trend line. The classification system is given in Table 2.

On the basis of the dense sampling grid area-wide maps were interpolated in ArcGIS 9.1 using the geostatistical analyst tool. The deterministic interpolation "Radial Basis Functions" was chosen because the results fit best to our own field observations and compared to other interpolation methods like "Kriging" it did not generalise too much. A Digital Elevation Model (DEM) based on 4046 data points was also calculated in ArcGIS 9.1. The elevation data was surveyed in October 2004 whereby field measurements were supplemented by data derived from aerial photographs which were taken at the same time.

We compared our current study with surveys by Wohlenberg (1937), Felix (1981) and Austen (1990). The old sediment maps were scanned with a resolution of $400 \mathrm{dpi}$, georeferenced and digitised in ArcGIS 9.1. As the former surveys used a coarser sediment classification system our

Table 2 The classification of the development trends of the sediments

\begin{tabular}{ll}
\hline Trend & Incline/decline of trend line \\
\hline Finer (T 1) & $<-0.1$ \\
Slightly finer (T 2) & -0.02 to -0.1 \\
No trend (T 3) & -0.02 to +0.02 \\
Slightly coarser (T 4) & 0.02 to 0.1 \\
Coarser (T 5) & $>0.1$ \\
\hline
\end{tabular}




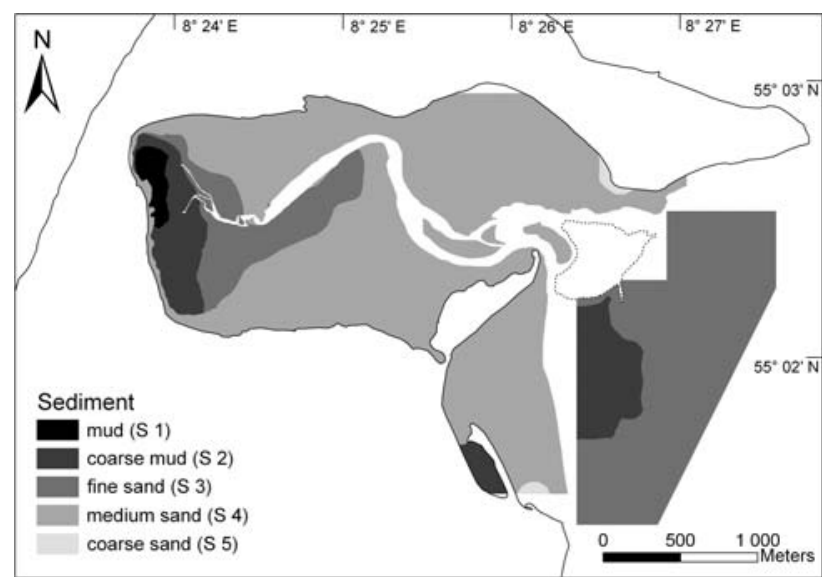

Fig. 3 Average surface sediment distribution in the Königshafen from 2003 to 2006

data had to be reclassified and interpolated again in order to make the results comparable to the earlier studies.

\section{Results}

Figure 3 shows the present distribution of five sediment classes in the Königshafen ranging from mud (S 1) to coarse sand (S 5). The muddy sediments (S 1) cover the innermost western part of the intertidal area which is $1.5 \%$ of the entire intertidal area. A strip of coarse mud (S 2; $5.5 \%$ ) adjoins it and stretches southwards, bordering a zone of fine sand (S 3). The fine sand forms a belt following the course of the tidal creek and covers $10.5 \%$ of the intertidal. Medium sand (S 4) can be found most in the inner Königshafen $(80 \%)$. In the sheltered location of a sandy hook in the south-eastern corner another zone of coarse mud (S 2; $1.5 \%$ ) established. Coarse sand (S 5) occurs just in the outer Königshafen, in vicinity to the subtidal. It appears close to

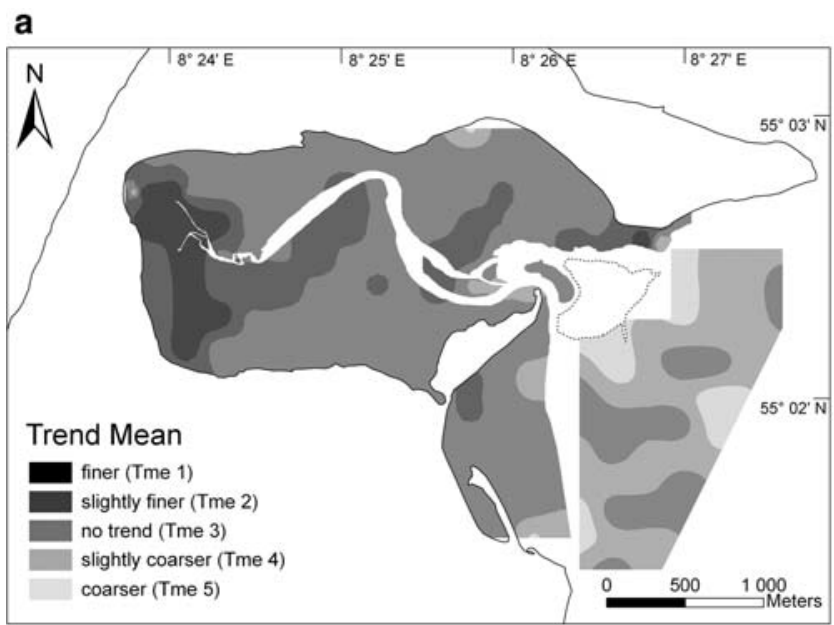

the shoreline and covers $1 \%$ of the intertidal area. It can be summarised that the finest sediments in the intertidal Königshafen occur in the inner part while the coarsest sediments occur close to the opening in the east. Compared to the intertidal, the subtidal sediments are dominated by fine sand (S 3;84\%). Only the south of the Uthörner Aussenwatt is characterised by coarse mud (S $2 ; 16 \%$ ).

The temporal trend in the sediment composition at each sampling location was classified into five groups ranging from a clear finer trend to a clear coarsening. Considering the "trend" of the sediments one has to be aware that this applies to the sampling period of 3 years. The average grain size (Mean) in the intertidal is becoming finer in the innermost part of the Königshafen (Tme 1; Fig. 4a). This area is almost congruent with the mud and coarse mud deposits and covers $8 \%$ of the intertidal area. Adjoining is a zone located where the mean grain size of the sediments is becoming slightly finer during the sampling period (Tme 2, covering $23 \%$ of the area). This zone also follows the course of the tidal creek similar to the occurrence of fine sands. Most sediments show no trend (Tme 3; 65\%), especially in the centre. In the north-eastern corner near intertidal mussel beds, the sediments are becoming slightly finer (Tme 2) and in the centre of the mussel beds even clearly finer (Tme 1) while they are getting slightly coarser (Tme 4) outside of them at the border to the subtidal. In the southeastern corner at the transition to the subtidal zone the mean grain size also tends to become slightly coarser (Tme 4). This continues in the subtidal area where the sediments are mainly getting slightly coarser (Tme $4 ; 55 \%$ ). In the northeastern part of the subtidal the sediments are becoming even clearly coarser (Tme 5; 17\%), while $28 \%$ of the subtidal area show no trend (Tme 3).

Compared to the Mean value the first Mode remains relatively stable and shows only few and weak trends (Fig. 4b). In the intertidal zone there is mainly no trend in

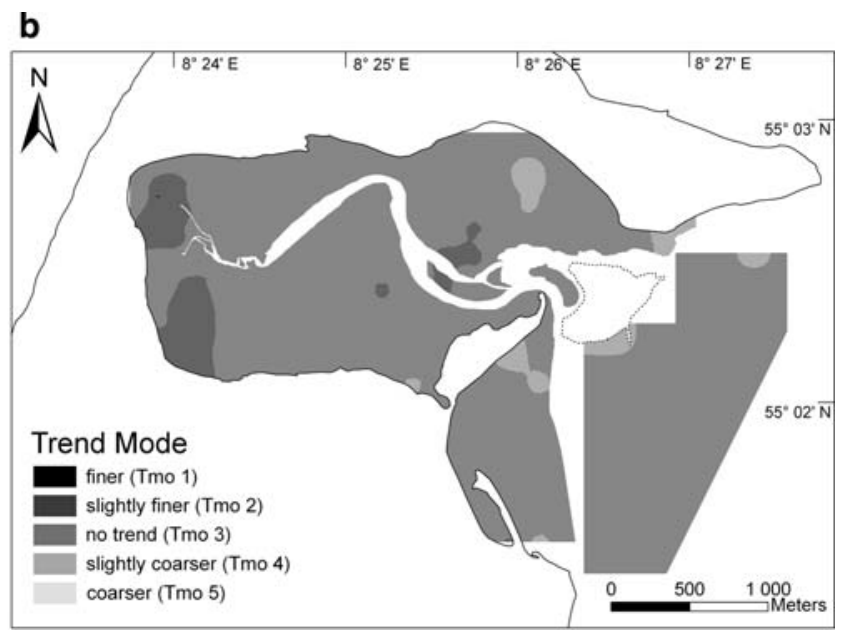

Fig. 4 Spatial distribution of the development trend in the grain size composition of the sediments from 2003 to 2006, Mean (a) and first Mode (b) 
the first Mode (Tmo 3, coverage: 89\%). It is getting slightly finer (Tmo 2; 8\%) in two areas in the innermost part of the Königshafen and in the centre near the tidal creek. Similar to the Mean, the first Mode also becomes slightly coarser (Tmo $4 ; 3 \%$ ) in few areas in the outer intertidal. This trend continues into the subtidal but applies only for two small areas in the northern part (Tmo $4 ; 5 \%$ ), yet $95 \%$ of the subtidal show no trend in the first Mode (Tmo 3).

\section{Discussion and conclusions}

In order to detect trends in the development of the Königshafen sediments, a long-term view is necessary. Therefore, we compared our survey with former studies by Wohlenberg (1937), Felix (1981) and Austen (1990). Due to different sampling and analysis methods it is not possible to precisely account the changes. Nevertheless, a more general comparison is allowed and gives a good idea how the
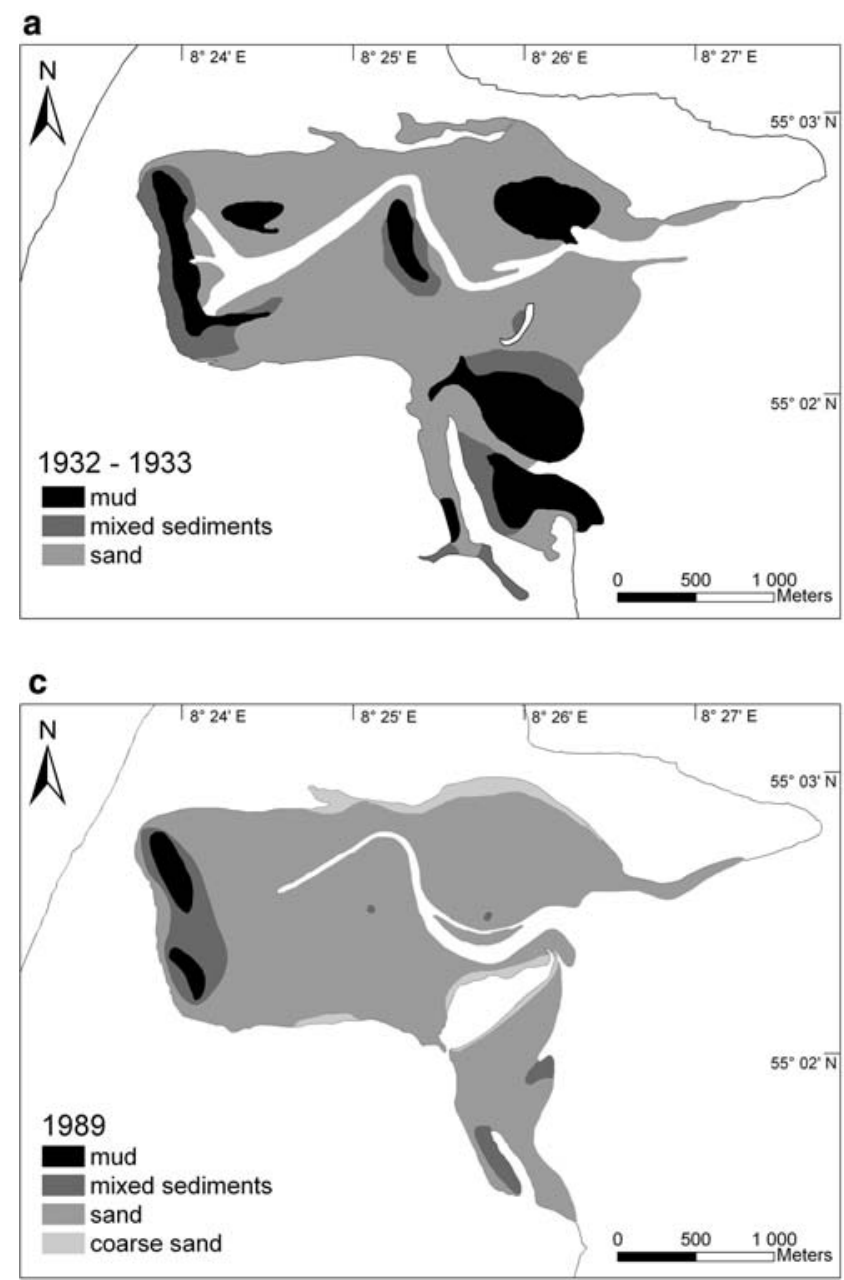

Fig. 5 a Sediment distribution in the Königshafen in 1932-1933 (Wohlenberg 1937). b Sediment distribution in the Königshafen in 1981 (Felix 1981). The white line indicates the border between inter- former sediment situation in the Königshafen was like and how the sediments developed.

Sediment development from 1932/1933 to 2003/2006

In 1932/1933 sand already dominated the intertidal, covering $68 \%$ of the area, but the large share of finer sediments is remarkable: $21 \%$ mud and $11 \%$ mixed sediments (Fig. 5a). Coarse sand is not recorded. In 1981 coarse sand makes up to $3 \%$ while medium sand covers $64 \%$, mixed sediments (including fine sand) $30 \%$ and mud 3\% of the intertidal area (Fig. 5b). Between 1932/1933 and 1981 most of the mudflats already disappeared. The sediment map from 1981 is the only former survey that also takes the subtidal into account. Fine sands and mixed sediments are dominant in the subtidal with some embedded muddy areas.

In 1989 sandy tidal flats cover $90 \%$ (including 5\% coarse sand) of the intertidal, while mixed sediments make up 7\% and mud 3\% (Fig. 5c). Today (2003/2006) the situation is

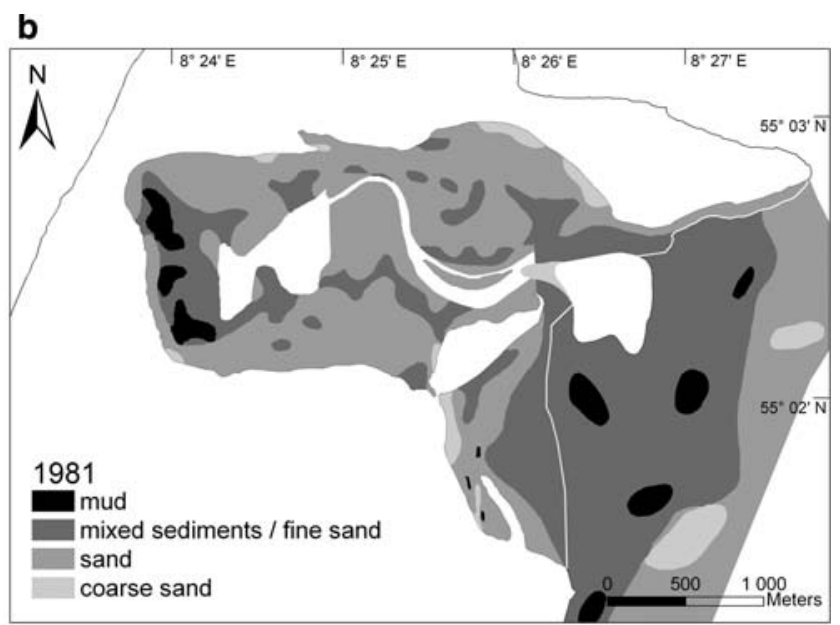

d

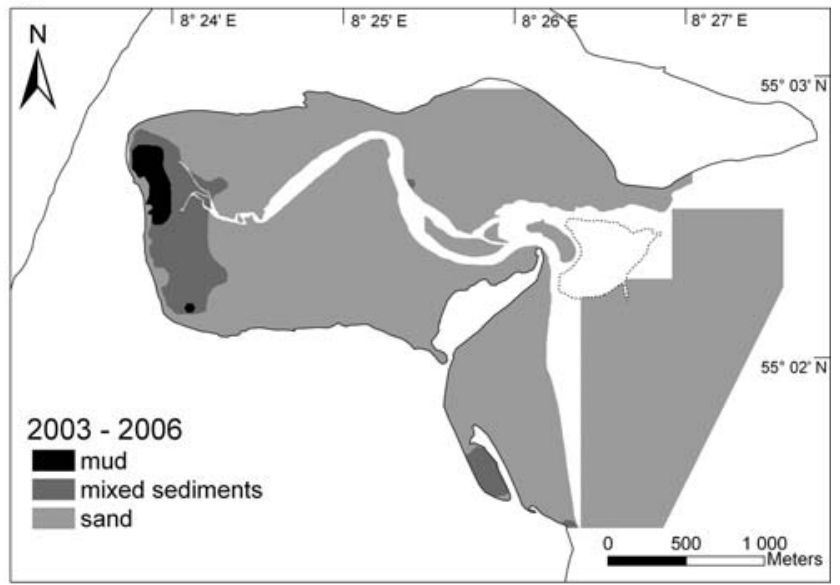

tidal and subtidal. c Sediment distribution in the Königshafen in 1989 (Austen 1990). d Sediment distribution in the Königshafen from 2003 to 2006 
very similar as the spatial share in the Königshafen is composed as follows: sandflats are covering $90 \%$ while mixed sediments and mud are covering 8 and $2 \%$ (Fig. $5 \mathrm{~d}$ ). According to this coarser classification system, coarse sand does not appear. Not many changes can be observed in the intertidal since 1989 because most of the mud has already been depleted. Comparing the sediment situation in the subtidal with the survey results from 1981 it becomes obvious that no more mud cores can be found and the share of mixed sediments also declined.

Not only the spatial extent but also the spatial distribution of the sediments in the Königshafen changed. In 1932/ 1933 the mudflats occur mainly in the outer Königshafen at the transition to the subtidal and still in 1981 larger extents of mixed sediments and fine sands can be found here and along the entire course of the tidal creek. Whereas in 1989 and today the muddy and mixed sediments vanished from the outer Königshafen except from the sheltered location of the sandy hook.

Altogether, a steady shift in the sediment composition and in the spatial extent of the different sediments can be observed over the years: Sandy tidal flats are becoming more and more dominant at the cost of areas with finer sediments. This general coarsening is so distinct that it affects the Mean and first Mode. The reason for this is not reduced supply of fine-grained sediments but the depletion of fines. Pejrup et al. (1997) conclude that the net deposition of finegrained sediment in a tidal basin is mainly a function of physiographical and hydrodynamical parameters and to a lesser degree of sediment availability. Since the "filter" rate of fine-grained sediment out of the sea water is very low in the List tidal basin compared to other tidal basins in the Wadden Sea, it can be assumed that the supply is not a limiting factor (Pejrup et al. 1997).

\section{Causes for mud depletion}

The depletion of mud has two main causes: biological and hydrodynamic factors. The loss of finer sediments goes along with a decline in the vegetation cover. Wohlenberg (1937) described that mudflats were very often associated with growing or decaying vegetation of Fucus-associated with mussels - and seagrass (Zostera), especially in the outer Königshafen. The vegetation provided sheltered areas where mudflats could establish. Especially seagrass is known to stabilise sediments and enhance deposition of fine-grained sediments (Ward et al. 1984; Fonseca and Fisher 1986; Heiss et al. 2000). According to aerial photographs from 1936 the vegetation covered about $31 \%$ of the intertidal while today's coverage is just about $9 \%$. Similar phenomena and possible reasons for this development are reported from other tidal flat areas. Cardoso et al. (2004) observed that after a decline of seagrass, the former vegetated area was replacement by coarser unvegetated sediments. Preceding changes in the physical forcings might have lead to the decline of seagrass. Da Silva et al. (2004) found out that increasing tidal wave penetration has induced transport of coarser sandy sediment into a lagoon and caused coverage of seagrass beds with sand and a reduction in sediment stability. In response seagrasses decreased substantially.

Wohlenberg (1937) also described that in 1932/1933 the muddy areas in the Königshafen were hardly walkable because of their extreme softness (sinking up to $1.2 \mathrm{~m}$ ). The vegetation retained water which led to slight water coverage in large parts of the tidal flats during low tide and to an oversaturation of the sediment with water. The sediments density was also broken up by decaying seagrass and Fucus that was included into the sediment and also made it soft. This situation has totally changed. Today, the maximum penetration into the mud is about $0.4 \mathrm{~m}$, the sediment is well drained and consolidated and the content of large organic particles is low (own observations). Obviously, the sediment characteristics changed from organic-rich, muddy tidal flat sediments to sandy siliclastic tidal deposits in less than 100 years.

The other factor that plays an important role in the depletion of fine-grained sediments is the increase of hydrodynamics caused by a rising sea level and the reduction of the tidal catchment area. According to the CPSL (2005) the annual mean high water level rose by $0.25 \mathrm{~cm} /$ year in the Wadden Sea from 1890 to 1989 and even by $0.67 \mathrm{~cm} /$ year for the period 1971-1989. A rising water level is associated with stronger currents that cause removal of fine-grained sediments. Furthermore, the reduction of the tidal catchment area leads to less accommodation space which results in increased energy levels within the basin (Flemming and Nyandwi 1994). The catchment area of the List tidal basin was mainly reduced by the construction of two causeways which connect the islands Sylt and $R ø m \varnothing$ with the mainland (see Fig. 1a). The construction of the Hindenburg causeway in the south in 1927 had a direct effect and caused immediate changes in the sedimentary system (Wohlenberg 1953). In 1948 the construction of the Røm $\varnothing$ causeway was finished and geomorphological changes as a immediate response were also observed (Jespersen and Rasmussen 1984). Furthermore, the catchment area was reduced by land reclamation measures, which were undertaken along the Danish mainland shore from 1954 to 1972 , and by the construction of a new dike in 1979-1982 whereby the Margrethe-Koog was formed (Jespersen and Rasmussen 1989).

Mud depletion as a result of the reasons mentioned above can be observed in the entire Wadden Sea. Flemming and Nyandwi (1994) and Mai and Bartholomä (2000) report it from the back-barrier tidal basin at the East Frisian Islands. Van Bernem (personal communication) found a 
coarsening trend in the Hörnum tidal basin south of the island of Sylt. In the Dutch Wadden Sea a landwarddirected shift of mud resulting in less mud in the more offshore tidal flats but also in more mud in the sheltered coastal areas is detected (Zwarts 2003).

Average spatial pattern of sediments from 2003 to 2006

The distribution of the different sediment types shows a distinct spatial pattern with fine sediments in the inner part and coarse sediments towards the outer parts of the intertidal Königshafen (see Fig. 3). Two factors contribute to the accumulation of the fine-grained sediments in the innermost part of the Königshafen: (1) low current velocities (Behrens et al. 1997; Backhaus et al. 1998) due to the sheltered position and (2) the morphology. The latter factor becomes apparent when draping in GIS the sediment layer over a Digital Terrain Model. The areas of mud, coarse mud and fine sand are almost congruent with a morphological depression at the head of the tidal creek. This depression has a predominant elevation of -0.8 to $-0.7 \mathrm{~m}$ while the sandy areas are considerably higher with mainly -0.3 to $0.2 \mathrm{~m}$. As a consequence, the water residence time in this small basin is extended which enhances the settlement of fines. Fine-grained sediments are easily kept in suspension and they need time and calm conditions to settle from the water column to the tidal flat. Furthermore, the sheltered position at the inner Königshafen allows the establishment of these fine-grained sediments whereby a gradient of increasing coarseness can be noticed towards the east. Another zone of coarse mud established in the sheltered lee side of the sandy hook in the south-east corner of the intertidal Königshafen where current velocities are usually low (Behrens et al. 1997).

The entire Königshafen is inherently in a sheltered position. It exists as a sheltered almost enclosed bay since the forming of the large sandy spit (Ellenbogen, see Fig. 1b) at its north between the middle of the seventeenth century and the end of the eighteenth century (Bayerl and Higelke 1994). It can be assumed that the currents were also in former times rather slow since this sand spit formation. So it is remarkably that there is a strong dominance of sandy tidal flats in the Königshafen which cannot be explained by the currents. According to the correlation between the grain settling velocities and the maximum flow velocities (Flemming and Nyandwi 1994), the current velocities are not high enough to transport a significant amount of sand into the bay. Austen (1994) found evidence for an aeolian input of sand into the Königshafen from surrounding dunes. Wohlenberg (1937) assumed that the high amount of sand can only be explained by migrating dunes. He presumes that the dunes originally migrated to the Königshafen and gushed and eroded into it. However, Bayerl and Higelke
(1994) proofed by analysis of sediment core data that beach and dune ridge sediments form up to $6 \mathrm{~m}$ thick layers right at the surface. Along a west-east profile they found out that the layer thickness is gradually decreasing westwards towards the subtidal. This goes along with our observation that the subtidal area is generally finer as the intertidal. It seems that input of medium sand is confined to the intertidal Königshafen.

The subtidal sediments consist mainly of fine sand. Coarse mud can only be found in the sheltered position south of the higher situated Uthörner Aussenwatt where mussel beds are located. Reise et al. (1994) stated that trapping efficiency of fine-grained material out of the water column is connected to benthic filter feeders forming faecal pellets of the fine-grained material and thereby enhancing the settling velocity of the fine sediment. Mussel beds affect the sediment composition by producing organic mud (Kröncke 1994) which explains the occurrence of finegrained material like coarse mud here in vicinity of the Uthörner Aussenwatt.

Trends in the development of surface sediments from 2003 to 2006

The mean grain size of the sediments in the innermost part of the Königshafen is becoming finer or at least slightly finer from 2003 to 2006 (Fig. 4a). Even though the spatial extent of the area of fine-grained sediments did not increase, the sediment composition in this area became finer over the sampling period. In contrast, a general coarsening characterises the sediments of the entire subtidal survey area and the outer, more exposed part of the intertidal.

In both cases the trend of the first Mode follows this spatial pattern but is far less pronounced (Fig. 4b). The first Mode is much more stable whereby the clearness as well as the spatial extent of the trend is far less compared to the Mean. Regarding the sediments grain size composition this means that the bulk (first Mode) remains the same and the changes which are caused by the increased mud deposition in the innermost part and the removal of mud in the outer Königshafen can be seen in the varying Mean. These opposed developments can be explained by the different impacts of waves and currents. As mentioned above a considerable annual rise of the sea level is observed in the Wadden Sea (CPSL 2005). This is associated with stronger currents that may remove mud. This affects the outer Königshafen as it is located close to one of the main tidal channels of the List tidal basin. Furthermore, it can be assumed that a deposition of mud is hindered here due to more turbulent conditions in the water column.

In contrast to this, waves are more responsible for resuspension of fine-grained sediments than tidal currents in shallow terrain (French et al. 2000, Janssen-Stelder 
2000)—like the inner Königshafen. Especially during storm events a lot of resuspension and erosion happens (Janssen-Stelder 2000; Bartholdy and Aagaard 2001) whereby wind-induced waves play an important role. Weisse and Plüß (2006) showed that storms decreased along the North Sea coast since the mid 1990s. It can be assumed that the innermost Königshafen is too shallow and sheltered so that-unlike in the outer Königshafen - the higher current velocities had no crucial impact yet. Furthermore, decreasing storm events lead to a reduced resuspension of the accumulated mud and to a positive net balance in the innermost Königshafen. Even though a lot of mud depletion has been detected over the last decades, these calmer years apparently enabled mud deposition.

Erosion and accumulation are opposite developments which are not only observed in the Königshafen but also in the List tidal basin. Pejrup et al. (1997) found out that the entire List tidal basin is a net sink for muddy sediments ( $<4 \mathrm{Phi}$ ) with an annual deposit of about 49,000 tons on the tidal flats. A positive annual net deposition of 1.4 tons is allotted to the Königshafen (Larsen et al. 1996). But in the long-term view, the tidal flats of the List tidal basin show a negative mass balance since the loss or submersion of intertidal areas was dominant in the last centuries (Higelke 1998; Reise 1998). This affects mainly the tidal flats in the inner part of the bight which are more exposed. Therefore, it can be assumed that the deposition of fines in the List tidal basin is first of all restricted to the areas of mixed and muddy sediments which occur mainly in close vicinity to the coastline. These fine sediments form narrow stripes at the margins of the List tidal basin and cover 25 and $3 \%$ of the intertidal area, respectively. The phenomenon that deposition of fines happens first of all in sheltered marginal areas coincides with our surveys in the Königshafen.

In summary, from 1932/1933 to 2003/2006 a severe depletion of mud due to a reduced vegetation cover and increased hydrodynamics was observed in the Königshafen. Today, a distinct spatial pattern with a gradient of increasing grain size coarseness from sheltered to exposed area can be observed in the intertidal survey area. Furthermore, an opposed development in the sheltered and the exposed area becomes obvious with accumulation of fines in the inner part and a coarsening in the outer. The reason is the different impact of waves and currents on these locations.

Acknowledgments We thank Justus van Beusekom and Alexander Bartholomä for their helpful comments on the manuscript.

\section{References}

Austen I (1990) Geologisch-sedimentologische Kartierung des Königshafens (List auf Sylt) und Untersuchung seiner Sedimente. Diploma thesis, University of Kiel
Austen I (1994) The surficial sediments of Königshafen-variations over the past 50 years. Helgol Meeresunters 48:163-171

Backhaus J, Hartke D, Hübner U, Lohse H, Müller A (1998) Hydrography und Klima im Lister Tidebecken. In: Gätje Ch, Reise K (eds) Ökosystem Wattenmeer, pp 39-54

Bartholdy J, Aagaard T (2001) Storm surge effects on a back-barrier tidal flat of the Danish Wadden Sea. Geo-Mar Lett 20:133-141

Bayerl K-A, Higelke B (1994) The development of northern Sylt during the Latest Holocene. Helgol Meeresunters 48:145-162

Bayerl K-A, Köster R, Murphy D (1998) Verteilung und Zusammensetzung der Sedimente im Lister Tidebecken. In: Gätje Ch, Reise K (eds) Ökosystem Wattenmeer, pp 31-38

Behrens A, Gayer G, Guenther H, Rosenthal W (1997) Atlas der Strömungen und Wasserstände in der Sylt-Rømø-Bucht. GKSS Forschungszentrum, Geesthacht

Blott SJ, Pye K (2001) Gradistat: a grain size distribution and statistics package for the analysis of unconsolidated sediments. Earth Surf Process Landforms 26:1237-1248

Cardoso PG, Pardal MA, Lillebø AI, Ferreira SM, Raffaelli D, Marques JC (2004) Dynamic changes in seagrass assemblages under eutrophication and implications for recovery. J Exp Mar Biol Ecol 302:233-248

CPSL (2005) Coastal Protection and Sea Level Rise - Solutions for sustainable coastal protection in the Wadden Sea region. Wadden Sea Ecosystem No. 21. Common Wadden Sea Secretariat, Trilateral Working Group on Coastal Protection and Sea Level Rise (CPSL), Wilhelmshaven, Germany

Da Silva JF, Duck RW, Catarino JB (2004) Seagrasses and sediment response to changing physical forcing in a coastal lagoon. Hydrol Earth Syst Sci 8(2):151-159

Felix K-M (1981) Sedimentologische Kartierung und Untersuchung des Königshafens und der Gaten, Tiefs und Rinnen des Wattenmeeres von List/Sylt. Diploma thesis, University of ClausthalZellerfeld

Flemming BW, Nyandwi N (1994) Land reclamation as a cause of fine-grained sediment depletion in backbarrier tidal flats, southern North Sea. Neth J Aquat Ecol 28:299-307

Flemming BW, Bartholomä A (2003) Sedimentation und Erosion an der Nordseeküste. In: Lozán JL et al (eds) Warnsignale aus Nordsee und Wattenmeer, pp 57-60

Fonseca MS, Fisher JS (1986) A comparison of canopy friction and sediment movement between four species of seagrass with reference to their ecology and restoration. Mar Ecol Prog Ser 29:1522

French CE, Fench JR, Clifford NJ, Watson CJ (2000) Sedimentationerosion dynamics of abandoned reclamations: the role of waves and tides. Cont Shelf Res 20:1711-1733

Heiss WM, Smith AM, Probert PK (2000) Influence of the small intertidal seagrass Zostera novazelandica on linear water flow and sediment texture. N Z J Mar Freshw Res 34:689-694

Higelke B (1998) Morphodynamik des Lister Tidebeckens. In: Gätje Ch, Reise K (eds) Ökosystem Wattenmeer, pp 103-126

Janssen-Stelder B (2000) The effect of different hydrodynamic conditions on the morphodynamics of a tidal mudflat in the Dutch Wadden Sea. Cont Shelf Res 20:1461-1478

Jespersen M, Rasmussen E (1984) Geomorphological effects of the Rømø Dam: development of a tidal channel and collapse of a dike. Geografisk Tidsskrift 84:17-24

Jespersen M, Rasmussen E (1989) Margrethe-Koog: Landgewinnung und Küstenschutz im südlichen Teil des dänischen Wattenmeeres. Die Küste 50:97-154

Kröncke I (1994) Impact of biodeposition on macrofaunal communities in intertidal sandflats. Mar Ecol 17(1-3):159-174

Larsen M, Pejrup M, Edelvang K (1996) A fine-grained sediment budget for a small tidal area, Königshafen, Sylt, Germany. Dan J Geogr 96:1-10 
Mai S, Bartholomä A (2000) The missing mud flats of the Wadden Sea: a reconstruction of sediments and accommodation space lost in the wake of land reclamation. In: Flemming BW, Delafontaine MT, Liebezeit G (eds) Muddy coast dynamics and resource management. Elsevier, Amsterdam, pp 257-272

Pejrup M, Larsen M, Edelvang K (1997) A fine-grained sediment budget for the Sylt-Rømø tidal basin. Helgol Meeresunters 51:253268

Piersma T, Koolhaas A, Dekinga A, Beukema JJ, Dekker R, Essink K (2001) Long-term indirect effects of mechanical cockle-dredging on intertidal bivalve stocks in the Wadden Sea. J Appl Ecol 38:976-990

Reise K, Herre E, Sturm M (1994) Biomass and abundance of macrofauna in intertidal sediments of Königshafen in the northern Wadden Sea. Helgol Meeresunters 48:201-215

Reise K (1998) Coastal change in a tidal backbarrier basin of the northern Wadden Sea: are tidal flats fading away? Senckenb Marit 29:121-127
Volkenborn N, Reise K (2006) Lugworm exclusion experiments: responses by deposit feeding worms to biogenic habitat transformations. J Exp Mar Biol Ecol 330:169-179

Ward LG, Boynton WR, Kemp WM (1984) The influence of waves and seagrass communities and suspended particulates in an estuarine embayment. Mar Geol 59:85-103

Weisse R, Plüß A (2006) Storm-related sea level variations along the North sea coast as simulated by a high-resolution model 1958 2002. Ocean Dyn 56:16-25

Widdows J, Lucas JS, Brinsley MD, Salkeld PN, Staff FJ (2002) Investigation of the effect of current velocity on mussel feeding and mussel bed stability using an annular flume. Helgol Mar Res 56:3-12

Wohlenberg E (1937) Die Wattenmeer-Lebensgemeinschaften im Königshafen von Sylt. Helgoländer wiss Meeresunters 1:1-92

Wohlenberg E (1953) Sinkstoff, Sediment und Anwachs am Hindenburgdamm. Die Küste 2:33-94

Zwarts L (2003) Bodemgesteldheid en mechanische kokkelvisserij in de Waddenzee. RIZA Rapport, RIZA Lelystad 